\title{
PENGHIJAUAN DAERAH RESAPAN DI DESA PENPEN KECAMATAN MUNDU KABUPATEN CIREBON
}

\author{
Nurdiyanto \\ nurdiyanto@ugj.ac.id
}

Fathur Rohman

fathur.emreza07@gmail.com

Heri Mulyono

mulyonoh29@gmail.com

\section{UNIVERSITAS SWADAYA GUNUNG JATI}

\begin{abstract}
ABSTRAK
Pelaksanaan kegiatan pengabdian kepada masyarakat ini dilaksanakan di Desa Penpen Kecamatan Mundu Kabupaten Cirebon. Tujuan dari kegiatan pengabdian ini adalah menumbuhkan kesadaran masyarakat terhadap lingkungan sekitar, memelihara kondisi lingkungan dari bencana kekeringan di musim kemarau dan menjaga daerah resapan air dengan kegiatan penanaman pohon. Metode yang digunakan dalam kegiatan pengabdian kepada masyarakat adalah: kegiatan sosialisasi, penanaman pohon, serta kegiatan monitoring dan evaluasi. Pada bulan Februari 2021 dilaksanakan kegiatan sosialisasi di aula Desa Penpen Kecamatan Mundu Kabupaten Cirebon. Dalam kegiatan sosialisasi ini dijelaskan tentang manfaat dari penanaman pohon di daerah resapan di Desa Penpen. Bibit tanaman yang ditanam adalah jenis tanaman buah-buahan dengan varietas unggul. Setelah 15 hari penanaman, dilakukan kegiatan monitoring. Hasil monitoring dan evaluasi menandakan bahwa sosialisasi dilaksanakan sesuai jadwal, sebagian masyarakat dan stakeholders mengikuti dan menanggapi kegiatan pengabdian dengan memahami materi tentang penghijauan di daerah resapan, serta pohon hidup dan tumbuh berbuah di lokasi penanaman.
\end{abstract}

Kata kunci: Daerah Resapan, Lingkungan, Penghijauan, Sosialisasi.

\section{PENDAHULUAN}

Desa Penpen terletak di Kecamatan Mundu Kabupaten Cirebon. Desa ini memiliki luas wilayah sekitar 236 ha. Batas wilayah Desa Penpen di bagian utara adalah Desa Luwung, sebelah selatan Desa Sinarancang, sebelah barat Desa Setu Kaler dan sebelah timur berada di Gemulung. Desa ini berada di sekitar Kawasan Waduk Setu Patok yang merupakan daerah konservasi untuk mengendalikan resapan dan penghijauan. Sehingga teknik konservasi lahan sangat penting untuk desa (Eraku \& Koem, 2018).

Debit air Waduk Setu Patok semakin berkurang, akibat dari kemarau kemarau panjang yang terjadi di kawasan pantai utara Cirebon. Usaha yang dapat dilakukan untuk memperkecil akibat kekeringan di musim kemarau adalah konservasi sumber air melalui penghijauan (Wardani \& Putra, 
2020). Penghijauan di sekitar kawasan waduk nantinya dapat mengurangi sedimentasi yang terjadi sehingga pendangkalan di waduk tidak terlalu banyak. Tanaman yang ditanam pada daerah resapan di sekitar waduk dapat menjaga kondisi tanah ketika hujan turun. Pohon yang ditanam rapat juga berfungsi untuk menyerap air hujan dengan kemampuan kondisi tanah, selain itu penghijauan sebagai pengatur tata air mengurangi penguapan dan aliran permukaan sehingga akhirnya cadangan air tanah akan tersedia lebih lama (Anam \& Istiqomah, 2020). Pohon untuk penghijauan dipilih yang dapat menyimpan dan menyerap air diantaranya pohon buahbuahan.

Kondisi saat ini, yang harus dilakukan adalah melestarikan tanaman di sekitar waduk. Tidak sedikit tanaman yang telah ada di sekitar waduk harus dipelihara dengan baik. Penyebab utama menurunnya kualitas dan kuantitas sumber daya air tanah dapat disebabkan kurangnya lahan resapan (Renosori \& Hindersah, 2014). Oleh karena itu perlu diadakan penghijauan di Desa Penpen yang bermanfaat untuk menyimpan cadangan air pada daerah resapan.

\section{METODOLOGI PELAKSANAAN}

Pelaksanaan kegiatan pengabdian ini dibagi menjadi tiga bagian, yaitu: sosialisasi dilaksanakan di Desa Penpen Kecamatan Mundu Kabupaten Cirebon, penanaman bibit tanaman dan monitoring. Khalayak sasaran kegiatan pengabdian ini adalah: Pemerintah Desa Penpen Kecamatan Mundu Kabupaten Cirebon, dosen pengabdi Fakultas Teknik UGJ Cirebon, mahasiswa Fakultas Teknik UGJ Cirebon dan pemanfaat hasil penghijauan. Pelaksanaan kegiatan pengabdian kepada masyarakat dilakukan dengan penyuluhan atau sosialisasi tentang penghijauan daerah resapan.

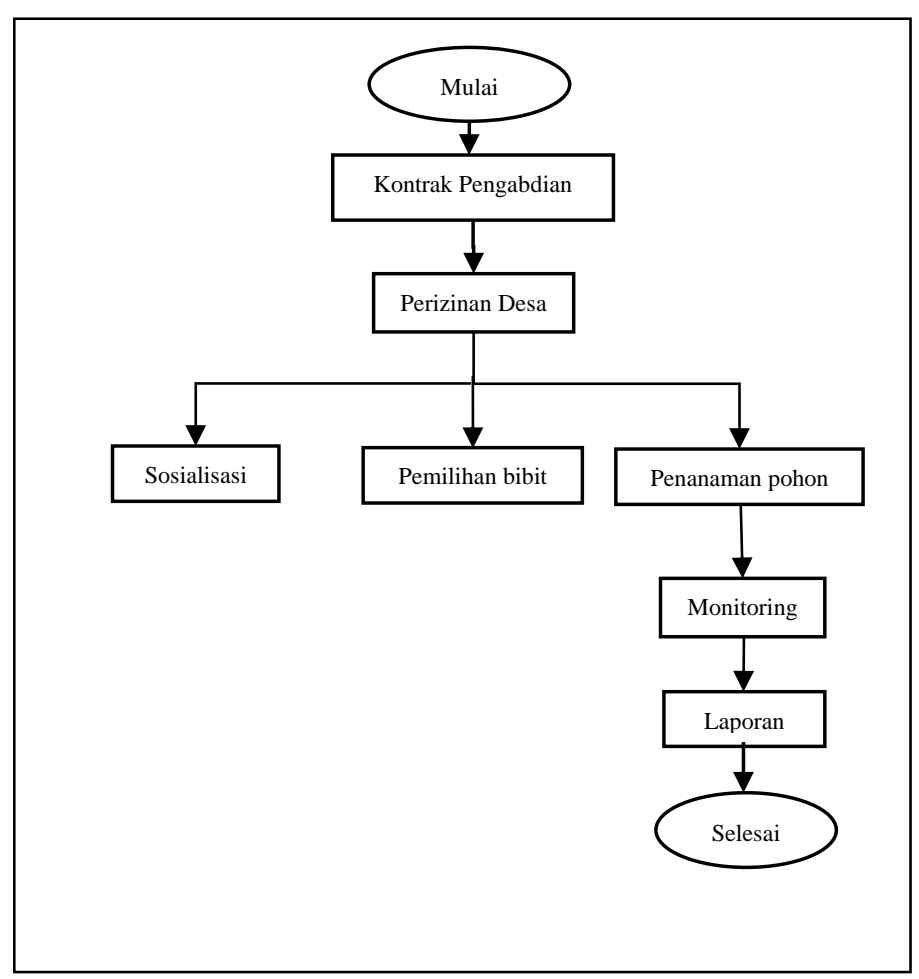

Gambar 1. Bagan alir pelaksanaan kegiatan pengabdian kepada masyarakat

Untuk kerangka kegiatan pengabdian kepada masyarakat ini dimulai dari kontrak pengabdian antara LPM UGJ dengan dosen pengabdi. Selanjutnya melakukan perizinan ke Desa Penpen. Setelah mendapat izin dari desa, dilakukan sosialisasi dengan para stakeholders di Desa Penpen. Beberapa materi yang dijelaskan dalam sosialisasi tersebut yaitu tentang reboisasi dan pemilihan bibit tanaman. Tahap selanjutnya adalah penanaman pohon. Pohon yang telah ditanam kemudian dimonitor sampai dengan kondisi pohon tersebut tumbuh dan tidak mati. terakhir yaitu pembuatan laporan dan luaran hasil pengabdian.

\section{HASIL DAN LUARAN}

Banyak manfaat yang dijelaskan dalam kegiatan sosialisasi ini terkait dengan kegiatan penanaman pohon untuk penghijauan daerah resapan. Kegiatan penanaman pohon dalam program penghijauan dapat meningkatkan kualitas lingkungan (Pratiwi, 2017). Setelah 
kegiatan sosialisasi, kemudian dilakukan diskusi dan tanya jawab dengan peserta mengenai kegiatan pengabdian selanjutnya.

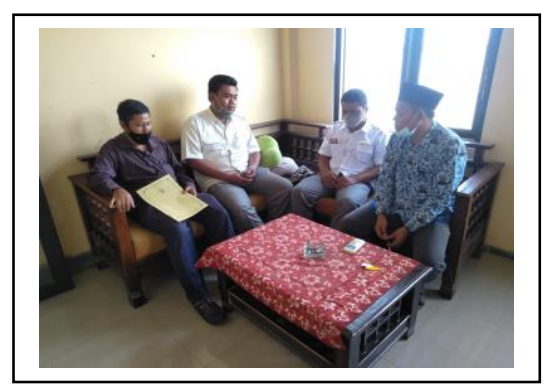

Gambar 2. Koordinasi dengan Kepala Desa

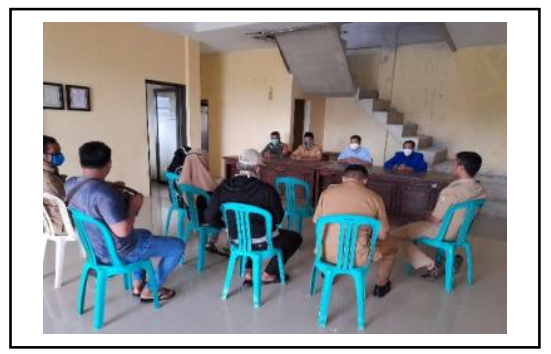

Gambar 3. Sosialisasi dengan stakeholder

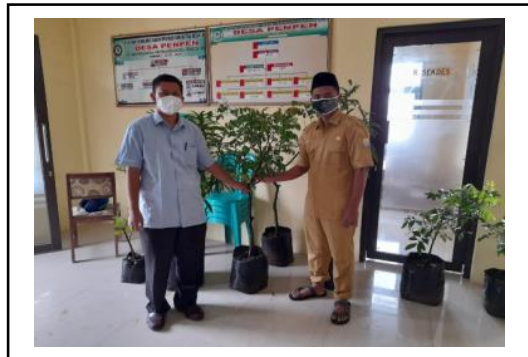

Gambar 4. Serah terima bibit tanaman

Pelaksanaan penanaman pohon dilaksanakan pada bulan Februari 2021. Pohon yang ditanam adalah bibit tanaman jenis buah-buahan dengan varietas unggul, yang terdiri dari buah manga, buah kelengkeng, buah jambu dan buah belimbing.

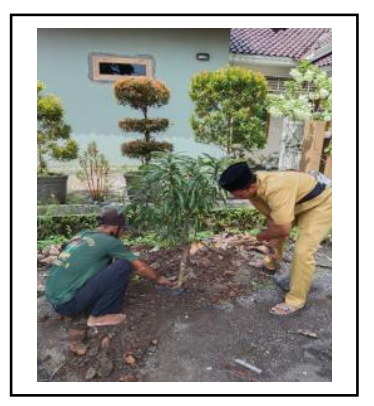

Gambar 5. Penanaman bibit tanaman

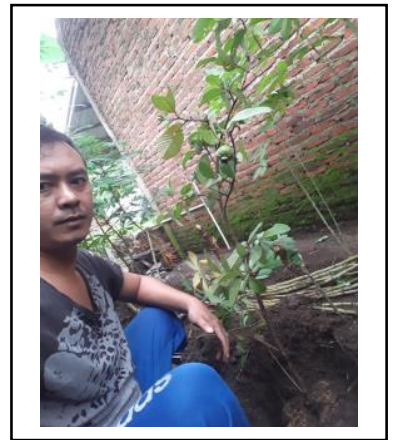

Gambar 6. Monitoring hasil tanam

Setelah 15 hari penanaman, dilakukan kegiatan monitoring. Hasil monitoring dan evaluasi menandakan bahwa:

a. Tingkat keberhasilan: Berhasil

b. Capaian Indikator Keberhasilan :

- sosialisasi dilaksanakan sesuai jadwal,

- sebagian masyarakat dan stakeholders mengikuti dan menanggapi kegiatan pengabdian dengan memahami materi tentang penghijauan di daerah resapan. Partisipasi masyarakat inilah yang sangat penting dalam mewujudkan pembangunan desa secara berkelanjutan, sehingga perencanaan pembangunan dapat dirasakan oleh setiap lapisan masyarakat, sebagaimana dijelaskan dalam Undang-Undang Nomor 6 Tahun 2014 Tentang Desa.

- pohon hidup dan tumbuh berbuah di lokasi penanaman

c. Hasil penghijauan ini dapat membentuk jaringan suatu tata ruang hijau khusus terintegrasi yang disebut Ruang Terbuka Hijau (RTH) (Damayanti, 2019) yang menjadi dasar dalam penataan kawasan daerah resapan. Dampak dari pengabdian kepada masyarakat adalah bahwa masyarakat Desa Penpen menyadari akan pentingnya daerah resapan dengan cara menanam tanaman. Tanaman menghasilkan buah-buahan yang dapat dinikmati oleh masyarakat sekitar. 


\section{KESIMPULAN DAN SARAN}

Kegiatan penghijauan daerah resapan dengan prinsip partisipasi masyarakat perlu dilakukan secara sinergi antara masyarakat dengan pemerintah desa. Pendampingan dari tim PKM dilaksanakan secara berkelanjutan untuk penanaman daerah resapan lainnya. Untuk kegiatan sosialisasi sebagian masyarakat dan stakeholders mengikuti dan menanggapi kegiatan pengabdian dengan memahami materi tentang penghijauan di daerah resapan. Pelaksanaan penanaman pohon dilaksanakan pada bulan Februari 2021, masyarakat turut andil dan aktif dalam kegiatan penanaman pohon. Jenis tanaman yang ditanam adalah tanaman buah-buahan dengan varietas unggul. Setelah 15 hari penanaman, dilakukan kegiatan monitoring dan evaluasi dengan kondisi tanaman tumbuh dan selanjutnya tanaman dipelihara oleh masyarakat sekitar.

\section{UCAPAN TERIMAKASIH}

Untuk kegiatan PKM ini mulai dari tahap persiapan pengabdian, pelaksanaan sampai dengan seminar nasional hasil pengabdian, kami sampaikan terima kasih kepada Bapak Rektor UGJ, Tim LPM UGJ, Fakultas Teknik UGJ, Pemerintah Desa Penpen Kecamatan Mundu Kabupaten Cirebon dan STIE Ekuitas atas kesempatan, dukungan, saran dan masukannya.

\section{DAFTAR PUSTAKA}

Diah, A.P. (2017). Pemberdayaan masyarakat rw 12 dalam kegiatan penghijauan lingkungan di kavling mandiri Kelurahan Sei Pelunggut. Jurnal Minda Baharu, 1(2), 25-32.

Hairul, A., \& Safira. (2020). Pemberdayaan masyarakat prapatan dalam rangka penghijauan lingkungan Kota Balikpapan. Jurnal Abdimas Universal, 2(1), 41-43.

Nila, R.W., \& Dwi, F.P. (2020). Pemberdayaan masyarakat melalui penghijauan untuk konservasi sumber air banyuning Kota Batu. Jurnal Abdimas Berdaya, 3(01), 1-8.

Puti, R., \& Hilwati, H. (2014). Meningkatkan kepedulian masyarakat terhadap konservasi air melalui sosialisasi melalui Lubang Resapan Biopori (LRB) dan penghijauan. Prosiding SNaPP2014 Sains, Teknologi dan Kesehatan, 4(1), 125132.

Sunarty, S.E., \& Syahrizal, K. (2018). Konservasi lingkungan berbasis masyarakat di Desa Motilango, Kabupaten Gorontalo Utara. Jurnal Ethos, 6(1), 107-113.

Verry, D. (2019). Potensi pengembangan infrastruktur hijau dalam mewujudkan Cimahi sebagai kota hijau berkelanjutan. Jurnal Ethos, 7(2), 233-243. 